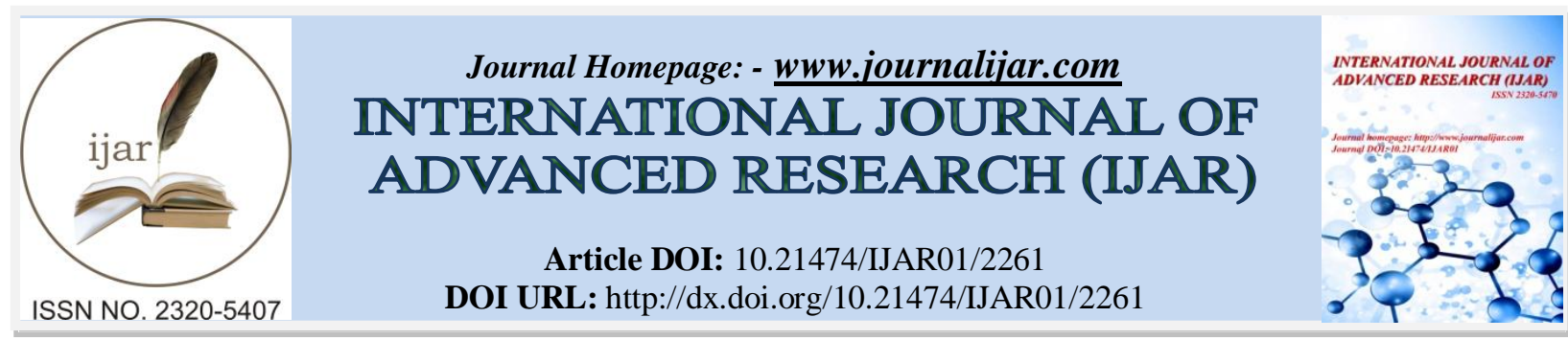

RESEARCH ARTICLE

\title{
A STUDY ON THE SATISFACTION LEVELS OF DOMESTIC AND FOREIGN TOURISTS WHO VISIT KERALA BEACHES.
}

Sini Raj S.

Research Scholar in Commerce, Kerala University Library Research Centre, University of Kerala.

\section{Manuscript Info}

Manuscript History

Received: 29 September 2016

Final Accepted: 30 October 2016

Published: November 2016

Key words:-

Satisfaction, Tourism and Travel.

\section{Abstract}

Tourism is treated as one of the excellent means for the promotion of domestic and foreign brotherhood. Tourism has given pleasure to countless number of travelers and holiday makers. Developments in information technology, transport and communication technology inspired man to travel. Once a person decides to travel he must be think where, when and how to go. A tourist always has an urge to discover the unknown, to travel around new and strange places. The level of satisfaction achieved from tourism depends on the present mindset of traveler.

Copy Right, IJAR, 2016,. All rights reserved.

\section{Introduction:-}

Pleasure is the key motive of the tourists that vary from person to person. Today, tourism has become the part of normal life irrespective of rich and poor. Tourism is recognized as one of the world's largest and fastest growing industry. Tourism industry plays a very significant role in promoting inter- state relationships and also international relationships.

India is one of the popular tourist destinations of Asia. As well as Kerala is one of the earliest States of India declaring tourism an industry in 1986. Kerala has an ancient tradition of tourism and tourism industry has been recorded continuous growth over the last few years. Kerala has amazing tourist places to rest and relax. There are 11 identified tourist destinations in Kerala as detected by the Government of Kerala during the year 2016. They are Back water, beaches, forts and palace, hills, monuments, museums, picnic spots, pilgrim, centres, palace of interests, wild life and waterfalls. Among the eleven categories of tourist destinations, present study focused on beaches. A total of 36 beaches are found in the study area.

A beach is a landform along a body of water, which are often composed of rocks and particles. Man made infrastructure of beaches enhance its beauty to great extent. It involves lifeguard posts, changing rooms, showers, and hospitality venues such as resorts, camps, hotels, and restaurants. Undeveloped or undiscovered beaches are known as wild beaches they, are not developed in this manner. Such type of beaches can be valued for their untouched beauty and preserved nature. Various beaches found in kerala are, Alappuzha, Bakal, Beypore, Chavakkad, Cherai, Chowara, Kanwarheera, Kappad, Kappil, Kappil beach and Backwaters, Kizhunna, Kolavi, Kollam, Kovalam, Kozhikode, Kuzhupilli, Light house, Meenkunnu, Munambam, Muuzhappilangad, Nattika, Neendakara, Pudinjareekara, Papanasham, Payyambalam, Poovar, Samudra, Shankhumugham, Thaikadappuram, Thalikulam Snehatheeram, Thikkotti Lighthouse, Thirumullavaram, Thiruvambadi, Vadakara sand banks, Vakkad beach and Tirur puzha, Valiathura, Vallikkunnu and Varkala.

Corresponding Author:- Sini Raj S.

Address:- Research Scholar in Commerce, Kerala University Library Research Centre, University of 


\section{Objective of the study:-}

Objective of the present study is to compare satisfaction levels of domestic and foreign tourists who visit Kerala beaches.

\section{Hypothesis of the study:-}

In view of the objective, the hypothesis are proposed to be tested in the study is there is no significant difference in the satisfaction levels of domestic and foreign tourists who visit Kerala beaches.

\section{Methods:-}

In the light of the above stated objectives and hypotheses, the methodology adopted for the present study is stated here.

Kovalam beach situated in Thiruvananthapuram district of Kerala, Chowara beach situated in Thiruvananthapuram district of Kerala and Papanasham beach situated in Kollam district of Kerala are selected for detailed investigation. The present study is conducted mainly on the reliance of primary sources of data. A structured interview schedule was prepared for this purpose. The total number of samples for the study was fixed at 150. Sample distribution is presented in Table 1

Table No.1:- Sample distribution.

\begin{tabular}{|l|l|c|c|}
\hline Sl. No & Name of beach & Domestic Tourists & Foreign Tourists \\
\hline 1 & Kovalam & 25 & 25 \\
\hline 2 & Chowara & 25 & 25 \\
\hline 3 & Papanasham & 25 & 25 \\
\hline Total & 75 & 75 \\
\hline
\end{tabular}

\section{Results and Discussion:-}

Present study was carried out to compare satisfaction levels of foreign and domestic tourists who visit Kerala beaches. Important variables such as Transportation facility, food and accommodation facility, health care facility, travel guidance and information, refreshment facility and relaxed regulations were taken for detailed investigation.

Profile of the respondents:-

Of the total of 150 respondents selected for detailed investigation 75 were in domestic tourists and other 75 were in foreign tourists. Brief profiles of sample respondents are narrated below.

Table 2:- Profile of the respondents.

\begin{tabular}{|c|c|c|c|c|c|}
\hline \multicolumn{2}{|l|}{ Characteristics } & \multicolumn{2}{|c|}{ Domestic } & \multicolumn{2}{|c|}{ Foreign } \\
\hline & & No. & $\%$ & No. & $\%$ \\
\hline \multirow[t]{5}{*}{ Age } & Below 20 & 15 & 20 & 6 & 8 \\
\hline & $21-30$ & 30 & 40 & 28 & 37 \\
\hline & $31-40$ & 15 & 20 & 17 & 23 \\
\hline & $41-50$ & 9 & 12 & 14 & 19 \\
\hline & Above 50 & 6 & 8 & 10 & 13 \\
\hline \multirow[t]{4}{*}{ Purpose of visit } & Academic & 3 & 4 & 7 & 9 \\
\hline & Pleasure & 69 & 92 & 60 & 80 \\
\hline & Business & 1 & 1 & 6 & 8 \\
\hline & Others & 2 & 3 & 2 & 3 \\
\hline \multirow[t]{5}{*}{ Stay duration } & Below 7 days & 67 & 90 & 59 & 79 \\
\hline & 7-14 days & 7 & 9 & 13 & 18 \\
\hline & 15-21 days & 1 & 1 & 1 & 1 \\
\hline & $22-28$ days & 0 & 0 & 1 & 1 \\
\hline & more than 28 days & 0 & 0 & 1 & 1 \\
\hline \multirow[t]{5}{*}{ Frequency of visit } & First time & 18 & 24 & 52 & 70 \\
\hline & Second time & 16 & 21 & 16 & 21 \\
\hline & Third time & 15 & 20 & 5 & 7 \\
\hline & Fourth time & 14 & 19 & 1 & 1 \\
\hline & Fifth and above & 12 & 16 & 1 & 1 \\
\hline
\end{tabular}

Source: Survey data 
Above Table disclosed that 20 per cent of domestic respondents belonging to below 20 age group whereas 8 per cent of foreign respondents belonging to below 20 age group. The highest turn out of domestic respondents and foreign respondents belonging to 21-30 age group are 40 per cent and 37 per cent respectively. 20 per cent of domestic respondents belonging to 31-40 age group, while it was 23 per cent in foreign respondents. 12 per cent of domestic respondents belonging to 41-50 age group whereas 19 per cent of foreign respondents belonging to 41-50 age group. Similarly, 8 per cent of domestic respondents belonging to Above 50 age group but it was 13 per cent in non-Indian respondents. The result of the study shows that majority of the respondents comes under 21-30 age group.

It can be seen from the Table No.2 that, 4 per cent of domestic respondents visited Kerala for academic purpose where as 9 per cent of foreign respondents visited Kerala for academic purpose. 92 per cent of domestic respondents visited Kerala for getting pleasure while it was 80 per cent in foreign respondents. 1 per cent of domestic respondents visited Kerala for business purposes while it was 8 per cent in foreign respondents. 3 per cent of domestic and foreign respondents visited Kerala for other purposes. It is concluded that majority of the respondents visit Kerala for pleasure.

From the table it is seen that 90 per cent of domestic respondents are staying in Kerala is below 7 days where as 79 per cent of non-Indian respondents are staying in Kerala is below 7 days. 9 per cent of domestic respondents and 18 per cent of foreign respondents stayed in Kerala in between 7-14 days. Similarly, 1 per cent of domestic and foreign respondents stayed in Kerala in between 15-21 days. It can be identified that none of the domestic respondents were stayed the stay durations of '22-28 days' and more than 28 days.

The study shows that 24 per cent of domestic respondents visited Kerala for the first time. Similarly, 70 per cent of foreign respondents visited Kerala for the first time. 21 per cent of both domestic and foreign respondents visited Kerala for the Second time. Domestic and foreign respondents visited for the third time are 20 per cent and 7 per cent respectively. The domestic and foreign respondents visited for the fourth time are 19 per cent and 1 per cent respectively. 16 per cent of domestic respondents and 1 per cent of foreign respondents visited for the fifth and above times. It can be concluded that majority of the Indian and non-Indian respondents visited Kerala for the first time.

\section{Satisfaction of the tourists:-}

Tourists visits Kerala for different purposes. Fulfillment of that purposes provides satisfaction to tourists both domestic and foreign. Here an attempt is made to compare satisfaction level of foreign and domestic tourists.

Table 3:- Extent of satisfaction of the tourists.

\begin{tabular}{|c|c|c|c|c|c|c|c|c|c|c|c|c|c|}
\hline Factors & \multicolumn{2}{|c|}{ Tourists } & $\begin{array}{l}\text { Very } \\
\text { low }\end{array}$ & $\begin{array}{c}\text { Lo } \\
\mathrm{w}\end{array}$ & $\begin{array}{c}\text { Avera } \\
\text { ge }\end{array}$ & $\begin{array}{c}\mathrm{Hig} \\
\mathrm{h}\end{array}$ & $\begin{array}{l}\text { Very } \\
\text { high }\end{array}$ & $\begin{array}{c}\text { Mea } \\
\mathrm{n}\end{array}$ & S.D & $\mathrm{t}$ & Sig. & $F$ & Sig. \\
\hline \multirow{4}{*}{$\begin{array}{l}\text { Transportat } \\
\text { ion facility }\end{array}$} & \multirow{2}{*}{$\begin{array}{c}\text { Domes } \\
\text { tic }\end{array}$} & $\mathrm{n}$ & 6 & 6 & 26 & 16 & 21 & 3.53 & 1.21 & 25.2 & 0.00 & \multirow{4}{*}{$\begin{array}{c}28.06 \\
8\end{array}$} & 0.00 \\
\hline & & $\%$ & 7.1 & 7.1 & 31.0 & $\begin{array}{c}19 . \\
0\end{array}$ & 25.0 & 3 & 1 & 51 & 0 & & 0 \\
\hline & \multirow{2}{*}{$\begin{array}{c}\text { Foreig } \\
n\end{array}$} & $\mathrm{n}$ & 18 & 24 & 19 & 7 & 7 & 2.48 & 1.22 & - & 0.00 & & \\
\hline & & $\%$ & 24.0 & $\begin{array}{c}32 . \\
0\end{array}$ & 25.3 & 9.3 & 9.3 & 0 & 3 & $\begin{array}{c}3.68 \\
2\end{array}$ & 0 & & \\
\hline \multirow{4}{*}{$\begin{array}{l}\text { Food } \\
\text { facility }\end{array}$} & \multirow{2}{*}{$\begin{array}{c}\text { Domes } \\
\text { tic }\end{array}$} & $\mathrm{n}$ & 5 & 10 & 30 & 18 & 12 & 3.29 & 1.10 & 25.9 & 0.00 & \multirow[t]{4}{*}{1.307} & 0.25 \\
\hline & & $\%$ & 6.0 & $\begin{array}{c}11 . \\
9\end{array}$ & 35.7 & $\begin{array}{c}21 . \\
4\end{array}$ & 14.3 & 3 & 0 & 27 & 0 & & 5 \\
\hline & \multirow{2}{*}{$\begin{array}{c}\text { Foreig } \\
n\end{array}$} & $\mathrm{n}$ & 12 & 12 & 24 & 13 & 14 & \multirow{2}{*}{$\begin{array}{c}3.06 \\
6\end{array}$} & 1.31 & \multirow[t]{2}{*}{.438} & 0.66 & & \\
\hline & & $\%$ & 16.0 & $\begin{array}{r}16 . \\
0\end{array}$ & 32.0 & $\begin{array}{c}17 . \\
3\end{array}$ & 18.7 & & 8 & & 3 & & \\
\hline \multirow{4}{*}{$\begin{array}{l}\text { Health care } \\
\text { facility }\end{array}$} & \multirow{2}{*}{$\begin{array}{c}\text { Domes } \\
\text { tic }\end{array}$} & $\mathrm{n}$ & 6 & 6 & 33 & 20 & 10 & 3.29 & 1.06 & 26.8 & 0.00 & \multirow[t]{4}{*}{3.358} & 0.06 \\
\hline & & $\%$ & 7.1 & 7.1 & 39.3 & $\begin{array}{c}23 . \\
8\end{array}$ & 11.9 & 3 & 2 & 42 & 0 & & 9 \\
\hline & \multirow{2}{*}{$\begin{array}{c}\text { Foreig } \\
n\end{array}$} & $\mathrm{n}$ & 12 & 19 & 19 & 12 & 13 & \multirow{2}{*}{$\begin{array}{c}2.93 \\
3\end{array}$} & 1.32 & \multirow[t]{2}{*}{-.434} & 0.66 & & \\
\hline & & $\%$ & 16.0 & $\begin{array}{r}25 . \\
3\end{array}$ & 25.3 & $\begin{array}{c}16 . \\
0 .\end{array}$ & 17.3 & & 8 & & 5 & & \\
\hline Travel & Domes & $\mathrm{n}$ & 5 & 5 & 21 & 22 & 22 & 3.68 & 1.16 & 27.3 & 0.00 & 29.22 & 0.00 \\
\hline
\end{tabular}




\begin{tabular}{|c|c|c|c|c|c|c|c|c|c|c|c|c|c|}
\hline \multirow{3}{*}{$\begin{array}{l}\text { guidance } \\
\text { and } \\
\text { information }\end{array}$} & tic & $\%$ & 6.0 & 6.0 & 25.0 & $\begin{array}{c}26 . \\
2\end{array}$ & 26.2 & 0 & 4 & 72 & 0 & \multirow[t]{3}{*}{0} & 0 \\
\hline & \multirow{2}{*}{$\begin{array}{c}\text { Foreig } \\
n\end{array}$} & $\mathrm{n}$ & 18 & 18 & 20 & 13 & 6 & \multirow{2}{*}{$\begin{array}{c}2.61 \\
3\end{array}$} & \multirow{2}{*}{$\begin{array}{c}1.25 \\
0\end{array}$} & - & 0.00 & & \\
\hline & & $\%$ & 24.0 & $\begin{array}{c}24 . \\
0\end{array}$ & 26.7 & $\begin{array}{c}17 . \\
3\end{array}$ & 8.0 & & & $\begin{array}{c}2.67 \\
7\end{array}$ & 9 & & \\
\hline \multirow{4}{*}{$\begin{array}{l}\text { Refreshme } \\
\text { nt facility }\end{array}$} & \multirow{2}{*}{$\begin{array}{l}\text { Domes } \\
\text { tic }\end{array}$} & $\mathrm{n}$ & 10 & 10 & 20 & 17 & 18 & \multirow{2}{*}{$\begin{array}{c}3.30 \\
6\end{array}$} & 1.33 & 21.4 & 0.00 & \multirow{4}{*}{$\begin{array}{c}11.71 \\
3\end{array}$} & \multirow{4}{*}{$\begin{array}{c}0.00 \\
1\end{array}$} \\
\hline & & $\%$ & 11.9 & $\begin{array}{c}11 . \\
9\end{array}$ & 23.8 & $\begin{array}{r}20 . \\
2\end{array}$ & 21.4 & & 5 & 46 & 0 & & \\
\hline & \multirow{2}{*}{$\begin{array}{c}\text { Foreig } \\
\mathrm{n}\end{array}$} & $\mathrm{n}$ & 6 & 6 & 6 & 18 & 39 & \multirow{2}{*}{$\begin{array}{c}4.04 \\
0\end{array}$} & 1.28 & 6.98 & 0.00 & & \\
\hline & & $\%$ & 8.0 & 8.0 & 8.0 & $\begin{array}{r}24 . \\
0\end{array}$ & 52.0 & & 8 & 9 & 0 & & \\
\hline \multirow{4}{*}{$\begin{array}{l}\text { Relaxed } \\
\text { regulations }\end{array}$} & \multirow{2}{*}{$\begin{array}{l}\text { Domes } \\
\text { tic }\end{array}$} & $\mathrm{n}$ & 0 & 0 & 20 & 15 & 40 & \multirow{2}{*}{$\begin{array}{c}4.26 \\
6\end{array}$} & 0.85 & 42.9 & 0.00 & \multirow{4}{*}{$\begin{array}{c}163.8 \\
57\end{array}$} & \multirow{4}{*}{$\begin{array}{c}0.00 \\
0\end{array}$} \\
\hline & & $\%$ & 0 & 0 & 23.8 & $\begin{array}{c}17 . \\
9\end{array}$ & 47.6 & & 9 & 91 & 0 & & \\
\hline & \multirow{2}{*}{$\begin{array}{c}\text { Foreig } \\
\mathrm{n}\end{array}$} & $\mathrm{n}$ & 24 & 24 & 18 & 6 & 3 & \multirow{2}{*}{$\begin{array}{c}2.20 \\
0\end{array}$} & 1.10 & - & 0.00 & & \\
\hline & & $\%$ & 32.0 & $\begin{array}{c}32 . \\
0\end{array}$ & 24.0 & 8.0 & 4.0 & & 2 & $\begin{array}{c}6.28 \\
2\end{array}$ & 0 & & \\
\hline
\end{tabular}

Source: Survey data

Above table reveals the extent of satisfaction of domestic and foreign tourists. 25 percent of domestic tourists have very high satisfaction in transportation facility where as only 9.3 per cent of foreign tourists have very high satisfaction in transportation facility. 19 percent of domestic tourists have high satisfaction in transportation facility where as only 9.3 per cent of foreign tourists have high satisfaction in transportation facility. 31.0 percent of domestic tourists have average satisfaction in transportation facility where as 25.3 per cent of foreign tourists have average satisfaction in transportation facility. 7.1 percent of domestic tourists have low satisfaction in transportation facility where as only 32.0 per cent of foreign tourists have low satisfaction in transportation facility. 7.1 percent of domestic tourists have very low satisfaction in transportation facility where as only 24.0 per cent of foreign tourists have very low satisfaction in transportation facility. Mean value of 3.533 indicated that satisfaction level of domestic tourist is above average level whereas mean value of 2.480 indicated that satisfaction level of foreign tourist is below average level. But in both cases satisfaction level variations in respect of this variable are seemed to be significant when t-test is applied. ANOVA test revealed that there is significant difference in the satisfaction levels of domestic and foreign tourists.

Analyses of the above table reveals that 14.3 percent of domestic tourists have very high satisfaction in food facility where as only 18.7 per cent of foreign tourists have very high satisfaction in food facility. 21.4 percent of domestic tourists have high satisfaction in food facility where as only 17.3 per cent of foreign tourists have high satisfaction in food facility. 35.7 percent of domestic tourists have average satisfaction in food facility where as 32.0 per cent of foreign tourists have average satisfaction in food facility. 11.9 percent of domestic tourists have low satisfaction in food facility where as only 16.0 per cent of foreign tourists have low satisfaction in food facility. 6.0 percent of domestic tourists have very low satisfaction in food facility where as only 16.0 per cent of foreign tourists have very low satisfaction in food facility. Mean value of 3.293 indicated that satisfaction level of domestic tourist is above average level whereas mean value of 3.066 indicated that satisfaction level of foreign tourist is average level. In case of domestic tourists satisfaction level variations in respect of this variable are seemed to be significant when t-test is applied. But in case of foreign tourists satisfaction level variations in respect of this variable are seemed to be not significant when $t$ test is applied. ANOVA test revealed that there is no significant difference in the satisfaction levels of domestic and foreign tourists.

It can be seen from the above table that 11.9 percent of domestic tourists have very high satisfaction in health care facility where as only 17.3 per cent of foreign tourists have very high satisfaction in health care facility. 23.8 percent of domestic tourists have high satisfaction in health care facility where as only 16.0 per cent of foreign tourists have high satisfaction in health care facility. 39.3 percent of domestic tourists have average satisfaction in health care facility where as 25.3 per cent of foreign tourists have average satisfaction in health care facility. 7.1 percent of domestic tourists have low satisfaction in health care facility where as only 25.3 per cent of foreign tourists have low satisfaction in health care facility. 7.1 percent of domestic tourists have very low satisfaction in health care facility where as only 16.0 per cent of foreign tourists have very low satisfaction in health care facility. Mean value of 3.293 
indicated that satisfaction level of domestic tourist is above average level whereas mean value of 2.933 indicated that satisfaction level of foreign tourist is below average level. In case of domestic tourists satisfaction level variations in respect of this variable are seemed to be significant when t-test is applied. But in case of foreign tourists satisfaction level variations in respect of this variable are seemed to be not significant when t test is applied. ANOVA test revealed that there is no significant difference in the satisfaction levels of domestic and foreign tourists.

Above table reveals that 26.2 percent of domestic tourists have very high satisfaction in travel guidance and information where as only 8.0 per cent of foreign tourists have very high satisfaction in travel guidance and information. 26.0 percent of domestic tourists have high satisfaction in travel guidance and information where as only 17.3 per cent of foreign tourists have high satisfaction in travel guidance and information. 25.0 percent of domestic tourists have average satisfaction in travel guidance and information where as 26.7per cent of foreign tourists have average satisfaction in travel guidance and information. 6.0 percent of domestic tourists have low satisfaction in travel guidance and information where as only 24.0 per cent of foreign tourists have low satisfaction in travel guidance and information. 6.0 percent of domestic tourists have very low satisfaction in travel guidance and information where as only 24.0 per cent of foreign tourists have very low satisfaction in travel guidance and information. Mean value of 3.680 indicated that satisfaction level of domestic tourist is above average level whereas mean value of 2.613 indicated that satisfaction level of foreign tourist is below average level. But in both cases satisfaction level variations in respect of this variable are seemed to be significant when t-test is applied. ANOVA test revealed that there is significant difference in the satisfaction levels of domestic and foreign tourists.

Above table shows that 21.4 percent of domestic tourists have very high satisfaction in refreshment facility where as only 52.0 per cent of foreign tourists have very high satisfaction in refreshment facility. 20.2 percent of domestic tourists have high satisfaction in refreshment facility where as only 24.0 per cent of foreign tourists have high satisfaction in refreshment facility. 23.8 percent of domestic tourists have average satisfaction in refreshment facility where as 8.0 per cent of foreign tourists have average satisfaction in refreshment facility. 11.9 percent of domestic tourists have low satisfaction in refreshment facility where as only 8.0 per cent of foreign tourists have low satisfaction in refreshment facility. 11.9 percent of domestic tourists have very low satisfaction in refreshment facility where as only 8.0 per cent of foreign tourists have very low satisfaction in refreshment facility. Mean value of 3.306 indicated that satisfaction level of domestic tourist is above average level. Similarly, mean value of 4.040 indicated that satisfaction level of foreign tourist is above average level. But in both cases satisfaction level variations in respect of this variable are seemed to be significant when t-test is applied. ANOVA test revealed that there is significant difference in the satisfaction levels of domestic and foreign tourists.

Analyses shows that 47.6 percent of domestic tourists have very high satisfaction in relaxed regulations where as only 4.0 per cent of foreign tourists have very high satisfaction in relaxed regulations. 17.9 percent of domestic tourists have high satisfaction in relaxed regulations where as only 8.0 per cent of foreign tourists have high satisfaction in relaxed regulations. 23.8 percent of domestic tourists have average satisfaction in relaxed regulations where as 24.0 per cent of foreign tourists have average satisfaction in relaxed regulations. 32 per cent of foreign tourists have low and very low satisfaction in relaxed regulations. Mean value of 4.266 indicated that satisfaction level of domestic tourist is above average level whereas mean value of 2.200 indicated that satisfaction level of foreign tourist is below average level. But in both cases satisfaction level variations in respect of this variable are seemed to be significant when t-test is applied. ANOVA test revealed that there is significant difference in the satisfaction levels of domestic and foreign tourists.

\section{Findings of the Study:-}

Major findings of the study are discussed below

1. Majority of the domestic tourists have average satisfaction in the transportation facility whereas majority of the foreign tourists show low satisfaction in the transportation facility.

2. Domestic and foreign tourists have only average satisfaction in food facility.

3. Foreign and domestic respondents visited in kerala feel average satisfaction in health care facilities.

4. Domestic respondents have high satisfaction in travel guidance and information whereas foreign respondents have only average satisfaction in travel guidance and information.

5. Domestic respondents show average satisfaction in refreshment facility whereas foreign respondents show high satisfaction. 
6. Domestic respondents are highly satisfied in travel rules and regulation. But foreign respondents are less satisfied.

\section{Recommendations of the study:-}

Suggestions for the study are point out below

1. Main problem of transportation facility is poor road and poor condition of vehicles. So Department of tourism should provide special attention to solve this problem.

2. Foreign and domestic respondents have special tastes and preferences. So prepare dishes after discussion with tourists.

3. Department of tourism should provide special attention to develop hospitals in each tourist places and appoint securities and staffs for cleaning purposes in all tourist places.

4. Department of tourism should give special attention to set up enquiry counters (nearest of all tourist destinations) for supplying information to tourists.

5. Refreshment facilities need to be innovating.

6. Travel rules and regulations should be liberalizing for the convenience of domestic and foreign tourists.

\section{Conclusion:-}

In Kerala, tourism has recorded continuous growth over the last few years. Kerala has amazing tourist places to rest and relax. Satisfaction level variations between domestic and foreign respondents depend on the purpose of visit. Domestic respondents show high satisfaction in relaxed regulations and travel guidance and information. Except these two cases domestic respondents shows average satisfaction. The study clearly gives the idea that all facilities need to be improved. The analysis revealed that there is a significant difference in transportation facility, travel guidance and information, refreshment facility and relaxed regulations between domestic and foreign tourists. But in case of food facility and health care facility study shows there is no significant difference between foreign and domestic tourists.

\section{References:-}

1. Krishnan.K.Kamra (2001), "Managing Tourist Destination”, Kanishka Publishers and Distributors-New Delhi.

2. A. Arulraj, B.Prabaharan(2010), "Methodology for Strategic Service Quality in Tourism", Serials Publications, New Delhi.

3. Sipra Mukhopadhyay(2008), "Tourism Economics", Ane Books India.

4. Tim Knowles(2001), "The Globalisation of Tourism and Hospitality", Continum, London.

5. M.Sarangdharan, G.Raju(2005), "Tourism and sustainable Development- Indian and Global Perspective", Century Publication. 